\title{
Whole Plant Photosynthesis, Development, and Carbon Partitioning in Potato as a Function of Temperature
}

\author{
Dennis Timlin,* S. M. Lutfor Rahman, Jeffery Baker, V. R. Reddy, David Fleisher, and Bruno Quebedeaux
}

\begin{abstract}
Knowledge of temperature effects on whole canopy photosynthesis, growth, and development of potato (Solanum tuberosum L.) is important for crop model development and evaluation. The objective of this study was to quantify the effects of temperature on canopy photosynthesis, development, growth, and partitioning of potato cv. Atlantic under elevated atmospheric $\mathrm{CO}_{2}$ concentration $\left(700 \mu \mathrm{L} \mathrm{L}^{-1} \mathrm{CO}_{2}\right)$. Potato plants were grown in day-lit plant growth chambers at six constant day/night temperatures, $\left(12,16,20,24,28\right.$, and $\left.32^{\circ} \mathrm{C}\right)$ during a 52-d experimental period in 1999 in Beltsville, MD. Main stem length and main stem expanded leaf number were measured nondestructively at $4 \mathrm{~d}$ intervals while leaf, stem, root, and tuber weights were obtained by destructive harvesting at biweekly time intervals. Canopy level net photosynthesis $\left(P_{N}\right)$ was obtained from gas exchange measurements. The optimum temperature for canopy photosynthesis was $24^{\circ} \mathrm{C}$ early in the growth period and shifted to lower temperatures as the plants aged. Total end-of-season biomass was highest in the $20^{\circ} \mathrm{C}$ treatment. End-of-season tuber mass and the ratio of tuber to total biomass decreased with increasing temperature above $24^{\circ} \mathrm{C}$. Accumulated biomass was a linear function of total $\mathrm{C}$ gain with a common slope for all treatments. However, the proportion of $\mathrm{C}$ allocated to tubers decreased with increasing temperatures. High respiration losses decreased total $\mathrm{C}$ gain at higher temperatures. When simulating photosynthesis and $\mathrm{C}$ assimilation in crop models, source-sink relationships with temperature and photosynthesis need to be accounted for.
\end{abstract}

$P$ otato is very sensitive to high temperatures. Temperatures of $31 / 29^{\circ} \mathrm{C}$ (day/night) in growth chambers reduced total plant dry matter by 44 to $72 \%$ after $4 \mathrm{wk}$ compared to a $19 / 17^{\circ} \mathrm{C}$ regime (Lafta and Lorenzen, 1995). Tuber weights were reduced relatively more than plant dry matter. Superoptimal temperatures resulted in taller plants with high stem dry weight and smaller leaves (Lafta and Lorenzen, 1995; Prange et al., 1990), and reduced tuber production for most cultivars (Ben Khedher and Ewing, 1985; Levy, 1986). Manrique and Bartholomew (1991) reported a negative correlation between minimum temperature and the ratio of tuber to total dry weight in a study that used elevation to control temperature. High temperatures extend the period of leaf growth, which ostensibly reduces net translocation of carbohydrates to the tubers (Marinus and Bodlaender,

D. Timlin, V.R. Reddy, and D. Fleisher, USDA-ARS-PSI, Crop Systems and Global Climate Change Lab., Bldg. 001, Room no. 342, BARC-W, 10300 Baltimore Ave., Beltsville, MD 20705-2350; S.M. Lutfor Rahman, Texas A\&M Univ., 17360 Coit Road, Dallas, TX 75252; J. Baker, USDA-ARS Cropping Systems Research Lab., 302 West I-20 Big Spring, TX 79720; and B. Quebedeaux, Univ. of Maryland, Dep. of Natural Resources Sciences and Landscape Architecture, Plant Science Bldg., Room 2130, College Park, MD 20742. Received 8 Sept. 2005. *Corresponding author (dtimlin@asrr.arsusda.gov).

Published in Agron. J. 98:1195-1203 (2006).

Potato

doi:10.2134/agronj2005.0260

(c) American Society of Agronomy

677 S. Segoe Rd., Madison, WI 53711 USA
1975). Physiological leaf aging is also increased at high temperatures (Menzel, 1985) accelerating leaf senescence and reducing the photosynthetic capacity of the canopy.

The optimum temperature for leaf photosynthesis in potato has been reported to be about $24^{\circ} \mathrm{C}(\mathrm{Ku}$ et al., 1977) and leaf photosynthetic rates rapidly decrease with increasing temperature (Wolf et al., 1990; Leach et al., 1982). Decreased leaf photosynthesis rate at high temperature is believed to be largely due to reduced efficiency in photosystem (PS) II rather than increased maintenance dark respiration or decreased leaf area (Prange et al., 1990). Accordingly, Thornton et al. (1996) did not find a relationship between dark respiration rates (leaf level) and biomass at harvest. Prange et al. (1990) further hypothesized that the decrease in tuber production was due to a reduction in tuber initiation resulting in a smaller sink for photosynthates. Research by Lafta and Lorenzen (1995) seems to support this view that the reduction in numbers of tubers at high temperature and concomitant reduction in sink strength reduce photosynthesis. Heat stress effects on photosynthesis in cotton (Gossypium hirsutum L.) and wheat (Triticum aestivum L.) have also been attributed to a decrease in the activation state of ribulose-1,5-bisphosphate carboxylase/oxygenase (Rubisco) via inhibition of Rubisco activase (Law and Crafts-Brandner, 1999).

Temperature also affects development rates of potato. The maximum development rate of potato has been reported to be within the range of 14 to $22^{\circ} \mathrm{C}$ (Driver and Hawkes, 1943; Yamaguchi et al., 1964; Marinus and Bodlaender, 1975; Sands et al., 1979). As temperatures increase to about $22^{\circ} \mathrm{C}$, the development phase from emergence to tuber initiation shortens (Kooman et al., 1996b). At higher temperatures, the time to tuber initiation increases (Ewing and Struik, 1992).

Detailed quantification of the effects of temperature on dry matter production and $\mathrm{C}$ partitioning is important to develop simulation models of potato as tools for growers to use in crop management. There are a number of potato models available (Wolf and van Oijen M. 2003; Hodges et al., 1992; Ingram and McCloud, 1984). The temperature dependencies used in these models have largely been developed from data collected in field trials and greenhouses (Ingram and McCloud, 1984), and using temperature gradients with altitude (Manrique and Bartholomew 1991). In all these cases, variations in temperature are reduced but there is no true control of temperature.

Although there have been detailed measurements on $\mathrm{C}$ partitioning as a function of temperature (Ingram and

Abbreviations: CER, carbon exchange rate; DAE, days after emergence; PAR, photosynthetically active radiation; $P_{\mathrm{N}}$, net photosynthesis; PPFD, photosynthetic photon flux density; PS II, photosystem II. 
McCloud, 1984), canopy level C assimilation was not measured in the same experiment. Photosynthesis measurements reported in the literature for potato are leaflevel measurements on plants grown in indoor chambers at average light levels near 400 to $500 \mu \mathrm{mol} \mathrm{m}{ }^{-2} \mathrm{~s}^{-1}$ (photosynthetic photon flux density, PPFD). Little is known, however, about whole canopy gas exchange rates in potato as a function of temperature and plant age under natural light levels where $\mathrm{C}$ is not limiting. Leach et al. (1982) measured whole canopy photosynthesis rates in potato in the field using enclosed chambers. They developed a detailed $\mathrm{C}$ budget for potatoes showing that plant growth rate was closely related to $P_{\mathrm{N}}$ rate but different temperatures were not investigated. Our objective was to quantify the effect of temperature on photosynthesis, respiration, $\mathrm{C}$ partitioning, and growth and phenology of potato. We used elevated $\mathrm{CO}_{2}$ levels $\left(700 \mu \mathrm{mol} \mathrm{mol}^{-1}\right.$ air) to reduce the effects of $\mathrm{C}$ stress on metabolic processes.

\section{MATERIALS AND METHODS}

The outdoor, day-lit controlled environment chambers used for this study were constructed of clear acrylic and are $2.3 \mathrm{~m}$ tall and $1.5 \mathrm{~m}^{2}$ in cross-sectional area with a total chamber volume of $3360 \mathrm{~L}$. Excluding the internal ducting, the space available for growing plants in the chambers is $1.0 \mathrm{~m}^{2}$. The soil plant atmosphere research (SPAR) chambers are very similar in design to those in use at Mississippi State University (Reddy et al., 2001).

A description of the chambers and the control mechanisms were fully described in Baker et al. (2004). The air handler, mounted at the base of the chamber, contains a squirrel cage fan that draws air and forces it past resistive heaters and a liquid cooled heat exchanger on the return path back to the chamber. These heating and cooling elements were used to control air temperature and humidity. Constant relative humidity was maintained at 60 to $70 \%$ by operating solenoid valves that inject chilled water through the cooling coils located in the air handler of each chamber. These cooling coils condensed excess water vapor from the chamber air stream to regulate relative humidity. The temperatures in the growth chambers were maintained to within $\pm 0.2^{\circ} \mathrm{C}$ of the set points.

A feed-forward, feed-back proportional-integral-differential (PID) control algorithm similar to the one described by Pickering et al. (1994) was used to control injection of $\mathrm{CO}_{2}$. The amount of $\mathrm{CO}_{2}$ injected, the air chamber volume, chamber temperature, and chamber leakage were used to calculate canopy photosynthetic and respiratory rates over 300-s intervals. Carbon dioxide was injected only during the daytime hours when there was sunlight, (0600-2000 h, eastern standard time, EST). The photosynthetically active radiation (PAR, measured as PPFD, $\mu \mathrm{mol}$ photons $\mathrm{m}^{-2} \mathrm{~s}^{-1}$ ) was integrated over the same 300 -s intervals.

The facility includes a dedicated Sun SPARC 5 work station (Sun Microsystems, Inc., Mountainview, CA) used to control chamber atmospheric $\mathrm{CO}_{2}$ concentration, and record $\mathrm{C}$ assimilation and chamber environmental data (air and soil temperatures, humidity, $\mathrm{CO}_{2}$ concentration, and solar radiation every $300 \mathrm{~s}$. Air temperature and relative humidity were also monitored and controlled with TC2 controllers (Environmental Growth Chambers, Inc., Chagrin Falls, OH). Incident photosynthetically active solar radiation (PAR) was monitored with a single Model LI 191 SB radiation sensor (LI-COR, Inc., Lincoln, NE) located inside one of the chambers.
Leakage rates were measured using resistance values from $\mathrm{CO}_{2}$ drawdown tests in empty cabinets at the end of the experiment and calculated as:

$$
L=\frac{1}{r}\left(\Delta \mathrm{CO}_{2}\right)
$$

Here $L$ is the leakage rate $\left(\mu \mathrm{mol} \mathrm{CO} \mathrm{CO}^{-2} \mathrm{~s}^{-1}\right)$, for example, the $\mathrm{C}$ exchange rate (CER) without plant uptake, and $\triangle \mathrm{CO}_{2}$ is the gradient of internal chamber to external air $\mathrm{CO}_{2}$ concentrations $\left(\mu \mathrm{mol} \mathrm{CO} \mathrm{Col} \mathrm{air}^{-1}\right)$. The $\mathrm{CO}_{2}$ levels in the chambers were increased to $1000 \mu \mathrm{mol} \mathrm{CO}_{2} \mathrm{~mol} \mathrm{air}^{-1}$ and then injection was stopped. Values of CER were recorded as the $\mathrm{CO}_{2}$ level decreased through diffusion out of the chamber. The value of the resistance, $r$, was obtained by regressing CER on the $\mathrm{CO}_{2}$ gradient $\left(\mathrm{ACO}_{2}\right)$. The relationship was strongly linear for all data. The gradients were calculated using ambient $\mathrm{CO}_{2}$ measurements taken on the same temporal scale as the $\mathrm{CO}_{2}$ measurements in the chambers. Ambient $\mathrm{CO}_{2}$ levels varied

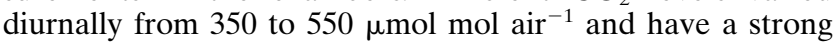
effect on leakage calculations (Baker et al., 2000).

When there were plants in the chamber, the CER represented $P_{\mathrm{N}}$. Dark respiration, $R_{D}\left(\mu \mathrm{mol} \mathrm{CO}_{2} \mathrm{~m}^{-2} \mathrm{~s}^{-1}\right)$, was calculated daily as the mean CER between the hours of 0100 and $0400 \mathrm{~h} . R_{D}$ does not account for photorespiration which was temperature dependent. A second order polynomial was used to model $P_{\mathrm{N}}$ as a function of PFD to interpolate measurements of $P_{\mathrm{N}}$ for periods when gas exchange data were missing or out of range as when the chambers were opened for plant measurements. Proc NLIN of SAS (SAS Institute, 1999) was used to fit the three coefficients. Values at a light level of $1200 \mu \mathrm{mol} \mathrm{m}^{-2} \mathrm{~s}^{-1}$ were also predicted for each curve and the standard error of the interpolated value was also recorded as an estimate of the error.

\section{Plant Cultivation and Measurements}

Three tuber cuttings (about $15 \mathrm{~g}$ each) of the potato $\mathrm{cv}$. Atlantic were planted into $3.8 \mathrm{~L}$ pots on 11 Aug. 1999. The pots were filled with one-fourth of each Promix, topsoil, sand, and vermiculite and the growing medium was amended with slow release fertilizer (Osmocote 14.0N-6.1P-11.6K, Scotts-Sierrra Horticultural Products Co., Marysville, $\mathrm{OH}$ ) and dolomitic lime at a rate of 4.5 and $2.4 \mathrm{~g} \mathrm{~L}^{-1}$, respectively. Sixteen pots were placed in each of the six chambers. The temperatures in the chambers were maintained at $20^{\circ} \pm 0.1^{\circ} \mathrm{C}$ day/night and ambient $\mathrm{CO}_{2}$ levels $\left(350 \mu \mathrm{mol} \mathrm{mol} \mathrm{air}{ }^{-1}\right)$ until shoot emergence. Upon emergence (22 Aug. 1999), two of the tubers were removed from the pot and the shoots thinned to one per pot. At this time, six temperature treatments were randomly assigned $\left(12,16,20,24,28\right.$, and $32^{\circ} \mathrm{C}$ day/night) to the six chambers. The data from the $12^{\circ} \mathrm{C}$ temperature treatment, however, were not included in the $\mathrm{C}$ assimilation analysis because poor $\mathrm{CO}_{2}$ control at night due to a sticking mass flow controller resulted in excessive errors in the gas exchange data. The daytime $\mathrm{CO}_{2}$ concentration was maintained at $700 \mu \mathrm{mol} \mathrm{mol}$ air $^{-1}$ in all treatments. Nighttime $\mathrm{CO}_{2}$ was not controlled and varied around the ambient level $\left(350-500 \mu \mathrm{mol} \mathrm{mol} \mathrm{air}{ }^{-1}\right)$. The plants were irrigated from drip tubes twice daily. Graded shade cloths were adjusted around the cabinet edges to plant height to simulate shading effects found in a field crop. The plants were not staked.

Additional newly emerged shoots from the tuber were removed by pinching to maintain one main stem shoot per pot. This should not affect photosynthesis rates via source-sink effects. Oparka and Davies (1985) did not find that there was sharing of assimilates among different stems emerging from the same seed-piece. When shoots are removed from 
volunteer potato in the field, tuber mass is reduced (Williams and Boydston, 2002). The effect, however, decreases as shoots are removed earlier in the growth cycle indicating that the remainder of the canopy adjusts for loss of a main-stem shoot. Volunteer potatoes are also sparsely distributed so that any change in leaf area can have a large effect on light interception. In this experiment, we removed the stems within 1 or $2 \mathrm{~d}$ of emergence and the plants were densely spaced.

To count main stem leaves at a higher frequency than the destructive harvests, four plants in each chamber were marked and the uppermost emerged leaf tagged as a reference for later counts. The numbers of main stem leaves on these tagged plants were counted two or three times per week throughout the growing season. Stem length was measured as distance from the lowermost leaf to the most recently emerged leaf at the tip of the top most apical stem. Destructive harvests were performed on 9 September and 23 September (18 and $32 \mathrm{~d}$ after emergence [DAE]) on plants from four pots per chamber. A final destructive harvest was performed on the remaining eight pots on 13 Oct. 1999, 52 DAE. During destructive harvest, the plants were separated into different plant parts and node and leaf numbers counted. Leaf area and dry mass of main stem and branch stem leaves, plant height, dry mass of root and tubers were also measured on nontagged plants.

The rooting medium in each pot was carefully removed and washed through a 1-mm sieve. All plant parts were then dried to constant weight at $75^{\circ} \mathrm{C}$. Leaf appearance rate was calculated for each temperature treatment as the slope of the regression of main stem node number vs. DAE.

\section{Carbon Budget}

Total cumulative $\mathrm{C}$ gain per day per plant was calculated from $P_{\mathrm{N}}$ and respiration as:

$A_{T}=\left(\sum_{06: 00}^{18: 00}\left[\left(P_{N}+R_{S}\right) \Delta t\right]-\left(R_{D}-R_{S}\right)(3600)(12)\right)$

(12)/Plants

Here, $A_{\mathrm{T}}$ is the total $\mathrm{C}$ accumulation $\left(\mathrm{g} \mathrm{C}_{\text {plant }}{ }^{-1}\right), P_{\mathrm{N}}$ is the $900 \mathrm{~s}$ average of $P_{\mathrm{N}}\left(\mathrm{mol} \mathrm{CO}_{2} \mathrm{~m}^{-2} \mathrm{~s}^{-1}\right)$ from Eq. [1], $\Delta t$ is time interval, $900 \mathrm{~s}, R_{\mathrm{D}}$ is dark respiration and $R_{\mathrm{S}}$ is $\mathrm{C}$ from root and soil respiration $\left(\mathrm{mol} \mathrm{CO}_{2} \mathrm{~m}^{-2} \mathrm{~s}^{-1}\right), 3600$ scales from seconds to hour, the first 12 in the numerator is the number of hours in the dark period. The second 12 is the molar weight of $\mathrm{C}$. To obtain total $\mathrm{C}$ gain per plant, the actual number of plants in the chamber $\left(1 \mathrm{~m}^{-2}\right)$ for the calculation period was used (Plants). This was 16 until the first harvest time, 12 from the second to the third harvest time, and 8 for the period from the second sample to final harvest. The values of $P_{\mathrm{N}}$ were summed from 0600 to $1800 \mathrm{~h} \mathrm{EST}$, the average hours of sunlight during the experimental period. The soil and roots potentially provide some $\mathrm{CO}_{2}$ through respiration. Values of about 1 to $2 \mu \mathrm{mol}$ $\mathrm{CO}_{2} \mathrm{~m}^{-2} \mathrm{~s}^{-1}$ have been reported for loblolly pine (Pinus taed $\mathrm{L}$.) grown in containers (Gough et al., 2004). Although this value is small relative to measured mean $300 \mathrm{~s}$ photosynthetic rates, it can be significant when accumulated over the growing period in a $\mathrm{C}$ budget. Carbon from soil respiration was accounted for by adding $R_{\mathrm{S}}$ to $P_{\mathrm{N}}$ and subtracting it from dark respiration. A mean value of $1.5 \mu \mathrm{mol} \mathrm{CO} \mathrm{Cm}^{-2} \mathrm{~s}^{-1}$ was used for $R_{\mathrm{s}}$. The daily values in [Eq. 2] were summed over the season to obtain seasonal cumulative assimilation of C. Although $R_{\mathrm{D}}$ does not account for photorespiration and may be affected by $\left[\mathrm{CO}_{2}\right]$, this method has successfully been used to relate $\mathrm{C}$ assimilation to dry matter (Dutton et al., 1988; Reddy et al., 1989; van Iersel and Kang, 2002) from growth chamber data.

\section{Statistical Analysis}

Regression was used to analyze the temperature response of the dry matter variables (leaf, aboveground biomass [leaf and stem], root, tuber and total biomass). The SAS procedure Proc Mixed (Littell et al., 1996; SAS Institute, 1999) was used to calculate the coefficients of the regression. The experimental design is a repeated measures analysis with temperature as a fixed effect, chambers as subjects, and harvest periods (DAE) as the repeated measurement. Temperature was treated as a continuous variable applied to the chambers. The covariance was modeled as an autoregressive response. There were four to eight replications of harvested plants (depending on time of harvest) for each subplot (harvest period). Regression lines were fit to the response of each dry matter variable to temperature and the regression coefficients tested for significance.

\section{RESULTS}

\section{Carbon Dioxide Assimilation}

The incident PAR inside the chambers averaged $35.3( \pm 14.1) \mathrm{mol} \mathrm{d}^{-1}$ from emergence to harvest (7.7 MJ $\mathrm{d}^{-1}$, using 4.57 as a conversion factor given by Thimijan and Heins, 1983). This low radiation is due to late summer conditions in Maryland and some attenuation of light by the acrylic chambers. Diurnal net canopy photosynthesis $\left(P_{\mathrm{N}}\right)$ and photosynthetic photon flux density (PPFD) for the five temperature treatments for a relatively cloudless day (31 DAE) is shown in Fig. 1. The maximum $P_{\mathrm{N}}$ for all treatments varies from 7 to $17 \mu \mathrm{mol}$ $\mathrm{CO}_{2} \mathrm{~m}^{-2} \mathrm{~s}^{-1}$ and occurs at about $1200 \mathrm{~h}$ (EST). The maximum $P_{\mathrm{N}}$ was measured in the 20 and $24^{\circ} \mathrm{C}$ treatments. The lowest rates were in the 28 and $32^{\circ} \mathrm{C}$ treatments.

The net canopy photosynthesis $\left(P_{\mathrm{N}}\right)$ as a function of PPFD was described by the polynomial equation well; the majority of the prediction errors ranged from 0.3 to $1.2 \mu \mathrm{mol} \mathrm{CO} \mathrm{Cm}^{-2} \mathrm{~s}^{-1}$ (data not shown). The temporal distribution of $P_{\mathrm{N}}$ throughout the growing season calculated from the polynomial equation at $1200 \mu \mathrm{mol} \mathrm{m}^{-2} \mathrm{~s}^{-1}$ PAR are shown in Fig. 2. Initially (up to $12 \mathrm{DAE}$ ), $P_{\mathrm{N}}$ was not significantly different among the temperature treatments. After $12 \mathrm{DAE}, P_{\mathrm{N}}$ increased rapidly and temperature effects began to differentiate. The $P_{\mathrm{N}}$ for

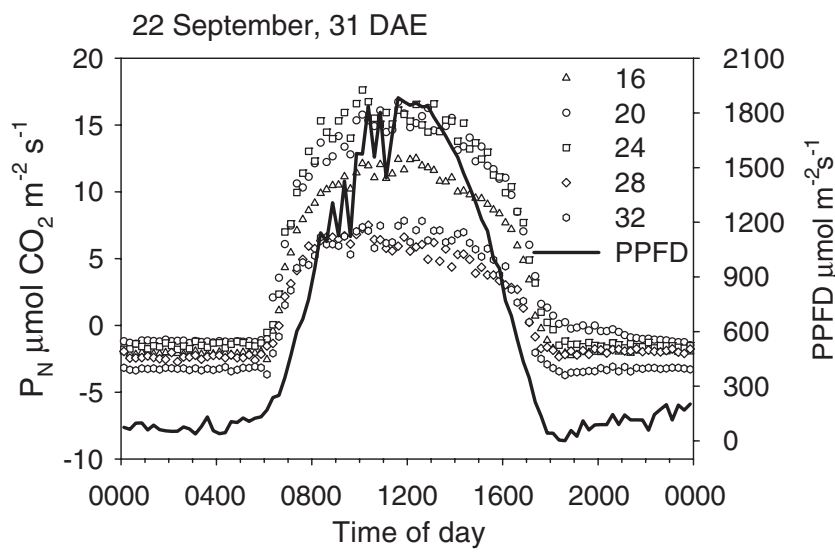

Fig. 1. Measured net photosynthetic rates $\left(P_{N}\right)$ and photosynthetically active solar radiation (PAR) as photosynthetic photon flux density (PPFD) for $1 \mathrm{~d}, 31 \mathrm{~d}$ after emergence (DAE) (22 Sept. 1999). The $12^{\circ} \mathrm{C}$ treatment is not shown. Data were recorded at $300 \mathrm{~s}$ intervals. 


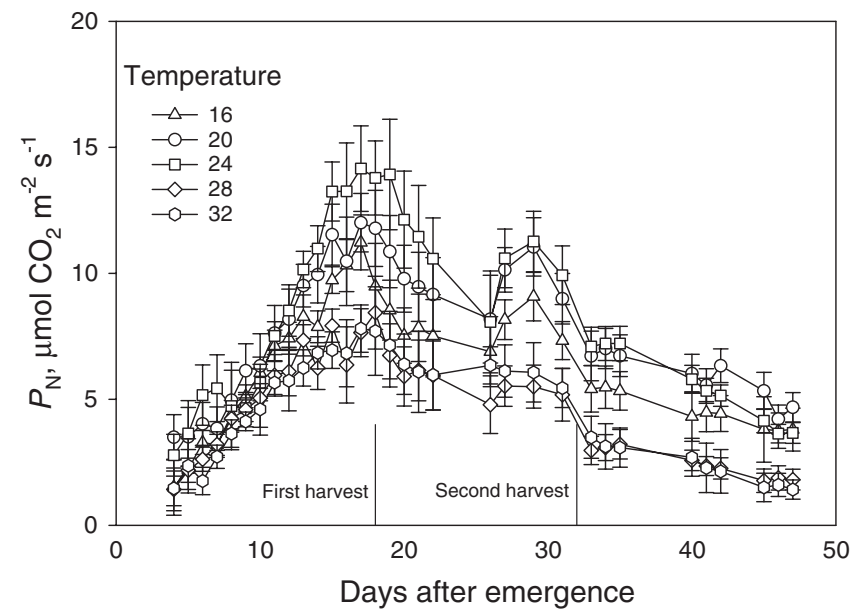

Fig. 2. Canopy net photosynthetic rate $\left(P_{N}\right)$ estimated from polynomial regression at $1200 \mu \mathrm{mol} \mathrm{m} \mathrm{m}^{-2} \mathrm{~s}^{-1}$ photosynthetic photo flux density (PPFD) for five temperatures throughout the growing season. Data are means of $900 \mathrm{~s}$ intervals. Gaps in the data result from days with low light levels that were not included in the analysis. The vertical bars indicate times when plants were removed from the chambers for destructive harvest.

most treatments attained their maximum values within 18 to $20 \mathrm{DAE}$. The potato plants in the two warmest temperature treatments approached their maximum canopy $P_{\mathrm{N}}$ values about 18 DAE (Fig. 2) then decreased thereafter. The $P_{\mathrm{N}}$ for the 16 and $20^{\circ} \mathrm{C}$ temperatures remained almost constant until the second harvest (DAE 32) whereupon they began to decrease. The $P_{\mathrm{N}}$ for the $24^{\circ} \mathrm{C}$ treatment, although initially highest, decreased sharply after the first harvest (18 DAE).

The temporal changes in respiration rates (Fig. 3) paralleled those of $P_{\mathrm{N}}$ (Fig. 2). The respiration rates increased for the first $18 \mathrm{~d}$ then reached a maximum at about 20 DAE. Respiration remained constant until the second harvest then declined thereafter. These rates are expressed on a square meter basis, but are actually a function of plant mass. Hence, the initial increase in res-

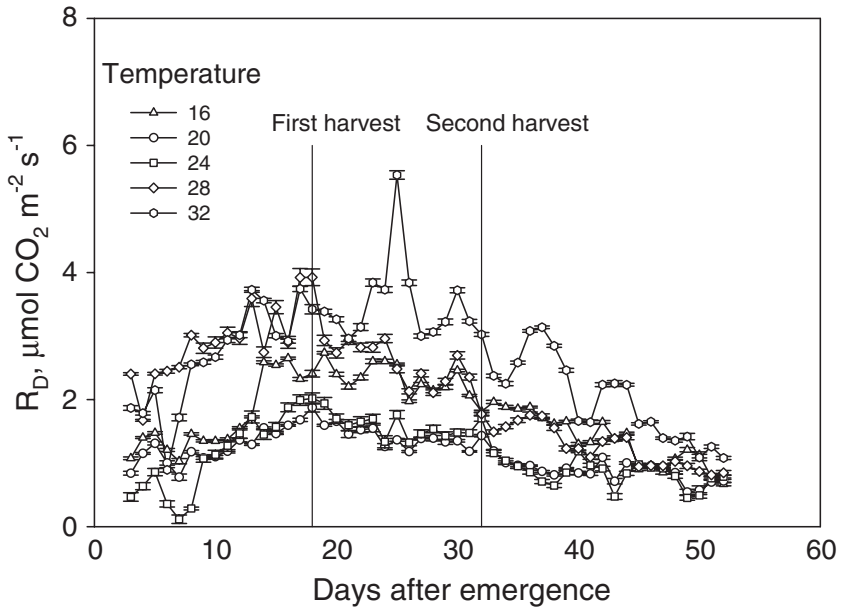

Fig. 3. Mean daily dark respiration $\left(R_{D}\right)$ as a function of temperature throughout the growing period. The error bars represent the variance about the mean. The vertical lines indicate the times plants were removed from the chambers for destructive harvest. PPFD = photosynthetic photon flux density. piration is related to the increasing mass of plant matter that represents the respiring plant tissue. The removal of plant material for harvest after DAE 18 countered the increase in plant mass due to growth likely resulting in a leveling of $R_{\mathrm{D}}$ values. The decreases at the end of the growing period are related to senescence and maturation of the plant tissue. The respiration rates for the 28 and $32^{\circ} \mathrm{C}$ temperatures were higher than those for the 20 and $24^{\circ} \mathrm{C}$ temperatures. It is only possible to distinguish gross temperature trends in the respiration data however since it is difficult to detect differences in $\mathrm{C}$ assimilation $<2 \mu \mathrm{mol} \mathrm{CO} \mathrm{Cm}^{-2} \mathrm{~s}^{-1}$ because the variability of the gas measurement system is in this range. KyeiBoahen et al. (2003) noted similar difficulties in detecting differences in respiration because of low magnitude.

The daily cumulative $\mathrm{C}$ gain values in Fig. 4 were calculated from Eq. [2]. The cyclic patterns in the cumulative $\mathrm{C}$ gain values are closely related to total daily light. Note that the total daily cumulative $\mathrm{C}$ gain is negative for the two highest temperatures for some days where light levels were low and loss of $\mathrm{C}$ via respiration was greater than $\mathrm{C}$ gained via photosynthesis. The maximum daily cumulative $\mathrm{C}$ gain was about $0.9 \mathrm{~g} \mathrm{C}_{\text {plant }}{ }^{-1}$ $\mathrm{d}^{-1}$ for the $24^{\circ} \mathrm{C}$ temperature. The higher temperatures of 28 and $32^{\circ}$ have lower maximum rates, about 0.25 to $0.35 \mathrm{~g} \mathrm{C}$ plant $^{-1} \mathrm{~d}^{-1}$. This is $0.9 \mathrm{~mol} \mathrm{CO}_{2} \mathrm{~m}^{-2} \mathrm{~d}^{-1}$ (12 plants $\mathrm{m}^{-2}$ ) on a chamber basis. Maximum daily net assimilation amounts for soybean [Glycine $\max (\mathrm{L}$.) Merr.] (Jones et al., 1985) from similar daylit growth chambers in Florida under elevated $\mathrm{CO}_{2}(660 \mathrm{umol} \mathrm{mol}$ air $^{-1}$ ) were larger, about $1.6 \mathrm{~mol} \mathrm{CO} \mathrm{m}^{-2} \mathrm{~d}^{-1}$. Similar data for sunflower (Helianthus annuus L.) (Hui et al., 2001) using sunlit chambers have maximum values of about $1.6 \mathrm{~mol} \mathrm{CO}_{2} \mathrm{~m}^{-2} \mathrm{~d}^{-1}$ under elevated $\mathrm{CO}_{2}$ levels $\left(600 \mu \mathrm{mol} \mathrm{mol} \mathrm{air}{ }^{-1}\right)$. The differences in this study may be partially attributable to the longer daylengths and

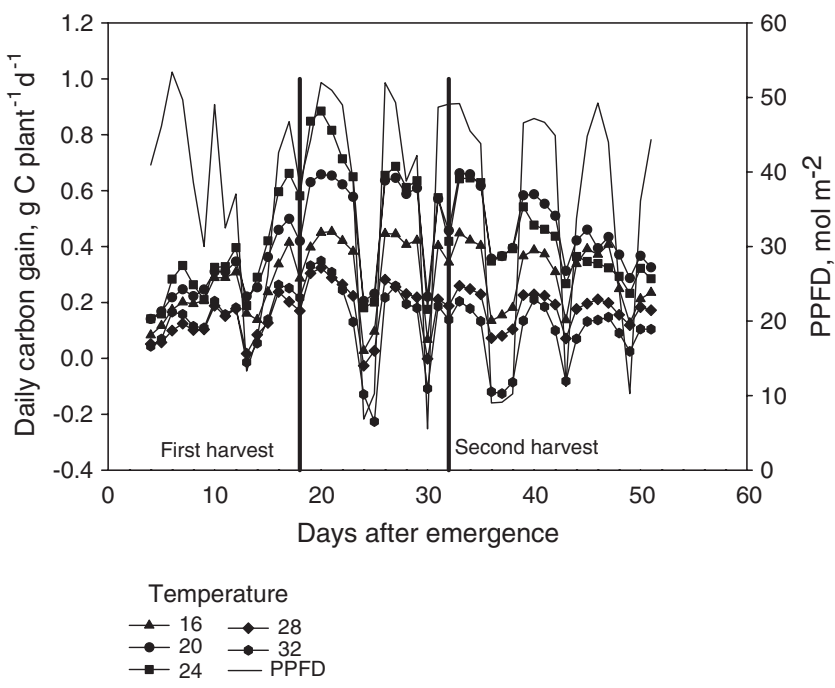

Fig. 4. Daily cumulative $C$ gain (as grams of $C$ per plant) and photosynthetic photon flux density (PPFD) throughout the growth period. The two vertical bars represent the times plants were removed from the chambers for destructive harvest. There were 16 plants up to the first harvest, 12 plants until the second harvest and eight plants until the final harvest at 52 DAE. 
Table 1. Relationship between stem length and time, and leaf emergence and time as functions of temperature. The intercepts and slopes are for the equations: Stem length $=\mathbf{a}+\mathbf{b}(\mathrm{DAE}) \dagger$ and leaf emergence $=\mathbf{a}+\mathbf{b}(\mathrm{DAE})$. The slopes (b) for leaf emergence fit the relationship with temperature as: Slope (b) $=0.042+0.095$ (Temperature),$r^{2}=0.96$.

\begin{tabular}{|c|c|c|c|c|}
\hline Temperature & Model & Intercept a & Slope b & Error \\
\hline${ }^{\circ} \mathbf{C}$ & & $\mathbf{c m}$ & $\mathrm{cm} \mathrm{d}^{-1}$ & $\mathbf{c m}$ \\
\hline 12 & Stem length & 4.40 & 0.38 & 1.47 \\
\hline 16 & & 3.22 & 0.98 & 1.83 \\
\hline 20 & & 1.83 & 1.05 & 2.35 \\
\hline 24 & & -2.84 & 1.52 & 5.33 \\
\hline 28 & & 6.36 & 1.31 & 2.02 \\
\hline \multirow[t]{3}{*}{32} & & 3.55 & 1.22 & 1.97 \\
\hline & Leaf emergence & & & \\
\hline & & No. of leaves & Leaves $\mathrm{d}^{-1}$ & No. of leaves \\
\hline 12 & & 4.22 & 0.28 & 0.53 \\
\hline 16 & & 4.72 & 0.35 & 0.64 \\
\hline 20 & & 4.38 & 0.42 & 0.62 \\
\hline 24 & & 2.42 & 0.53 & 1.10 \\
\hline 28 & & 4.88 & 0.54 & 0.84 \\
\hline 32 & & 3.32 & 0.70 & 0.44 \\
\hline
\end{tabular}

$\dagger$ DAE = days after emergence.

higher total daily radiation in these studies as well as species and plant population differences.

\section{Plant Development and Biomass}

The leaf addition rates increased with temperature and were maximal at the highest temperature $\left(32^{\circ} \mathrm{C}\right)$ (Table 1). The leaf emergence rates (slopes, $b$ in Table 1) could be predicted from temperature as: (Leaf emergence rate $)=0.042+0.095($ Temperature $), r^{2}=0.96$. Accordingly, there was also a significant linear affect for temperature on stem weight where stem weight increased with temperature (Tables 2 and 3). There were no significant time or temperature effects on leaf weight over the period the plants were harvested (Tables 2 and 3). There was a significant linear affect of temperature (slope same for all temperatures) on aboveground
Table 3. Intercepts and temperature coefficients for the regression of harvest components on temperature for three harvest dates.

\begin{tabular}{|c|c|c|c|c|c|c|c|}
\hline \multirow[b]{2}{*}{ Source } & \multirow{2}{*}{$\begin{array}{c}\text { Harvest } \\
\text { date }\end{array}$} & \multicolumn{2}{|c|}{ Intercept } & \multicolumn{4}{|c|}{ Slope } \\
\hline & & Int & SE & Linear & SE & Quadratic & SE \\
\hline & DAE $\dagger$ & $-\mathbf{g}$ & - & $-\mathbf{g}^{\circ} \mathbf{C}^{-}$ & -1 & $-\mathrm{g}^{\circ} \mathrm{C}^{-2}$ & \\
\hline Leaf weight & All & 4.58 & 0.28 & $\begin{array}{l}\text { NS } \\
\text { NS }\end{array}$ & & NS & \\
\hline \multirow[t]{3}{*}{ Stem weight } & 18 & -2.97 & 0.91 & 0.20 & 0.04 & NS & \\
\hline & 32 & -0.78 & 0.92 & 0.20 & 0.04 & NS & \\
\hline & 52 & -1.75 & 0.89 & 0.20 & 0.04 & NS & \\
\hline $\begin{array}{c}\text { Aboveground } \\
\text { dry weight }\end{array}$ & All & 2.36 & 1.83 & 0.22 & 0.08 & NS & \\
\hline \multirow[t]{3}{*}{ Root weight } & 18 & 9.35 & 1.61 & NS & & NS & \\
\hline & 32 & 8.74 & 1.62 & NS & & NS & \\
\hline & 52 & 13.66 & 1.24 & NS & & NS & \\
\hline \multirow{3}{*}{$\begin{array}{c}\text { Vegetative } \\
\text { weight }\end{array}$} & 18 & 6.88 & 3.49 & 0.36 & 0.14 & NS & \\
\hline & 32 & 9.11 & 3.49 & 0.36 & 0.14 & NS & \\
\hline & 52 & 12.71 & 3.41 & 0.36 & 0.14 & NS & \\
\hline \multirow[t]{3}{*}{ Tuber weight } & 18 & -61.07 & 16.17 & 6.23 & 1.52 & -0.14 & 0.0 \\
\hline & 32 & -38.52 & 16.24 & 6.23 & 1.52 & -0.16 & \\
\hline & 52 & -12.14 & 16.55 & 6.23 & 1.52 & $-\mathbf{0 . 1 8}$ & 0.0 \\
\hline \multirow[t]{3}{*}{ Total dry weight } & 18 & -56.97 & 19.95 & 7.08 & 1.79 & -0.15 & 0.0 \\
\hline & 32 & -35.57 & 19.95 & 6.70 & 1.79 & -0.15 & 0.04 \\
\hline & 52 & 12.09 & 20.23 & 5.42 & 1.82 & -0.15 & 0.04 \\
\hline
\end{tabular}

$\dagger$ DAE $=$ days after emergence.

$\$$ Not significant at $P<0.05$

biomass (stem + leaf) due to stem weight and there were no interactions with harvest date. Therefore, a common intercept and slope model fit the data best. Root weight did not have a significant temperature effect but the weight at 52 DAE was significantly higher than the weights at 18 and 32 DAE. The variability in the root weight was high which possibly masked potential temperature effects.

There were significant linear and quadratic temperature effects on tuber weight. The intercept increased with time. The linear slope of tuber weight on temperature was positive and constant for all harvest dates (DAE) and the quadratic slope decreased with time (Table 3). The existence of different quadratic coefficients

Table 2. Means and standard errors of dry matter components of potato for three harvests and six temperatures.

\begin{tabular}{|c|c|c|c|c|c|c|c|c|c|c|c|c|c|c|c|c|}
\hline $\begin{array}{l}\text { Days after } \\
\text { emergence }\end{array}$ & Temp. & n & Stem & SE & Leaf & SE & $\begin{array}{c}\text { Above ground } \\
\text { biomass }\end{array}$ & SE & Root & SE & $\begin{array}{c}\text { Vegetative } \\
\text { (Shoot }+ \text { Root) }\end{array}$ & SE & Tuber & SE & $\begin{array}{c}\text { Total } \\
\text { biomass }\end{array}$ & SE \\
\hline & ${ }^{\circ} \mathbf{C}$ & & $\mathbf{g}$ & & $\mathbf{g}$ & & $\mathbf{g}$ & & $\mathbf{g}$ & & $\mathbf{g}$ & & $\mathbf{g}$ & & $\mathbf{g}$ & \\
\hline 18 & 12 & 4 & 0.75 & 0.14 & 4.09 & 0.98 & 4.84 & 1.11 & 5.63 & 0.76 & 10.46 & 1.81 & 0.42 & 0.25 & 10.88 & 2.05 \\
\hline 32 & & 4 & 1.33 & 0.38 & 5.21 & 1.81 & 6.53 & 2.17 & 7.25 & 0.94 & 13.78 & 2.91 & 11.20 & 5.78 & 24.97 & 8.66 \\
\hline 52 & & 4 & 0.75 & 0.21 & 4.21 & 1.59 & 4.96 & 1.79 & 17.20 & 4.25 & 22.15 & 3.19 & 31.76 & 6.36 & 53.92 & 9.08 \\
\hline 18 & 16 & 4 & 0.65 & 0.27 & 4.20 & 1.46 & 4.85 & 1.73 & 6.29 & 1.03 & 11.13 & 2.74 & 1.30 & 0.91 & 12.43 & 2.53 \\
\hline 32 & & 4 & 0.97 & 0.16 & 3.45 & 0.51 & 4.42 & 0.66 & 6.09 & 0.13 & 10.52 & 0.7 & 14.67 & 3.21 & 25.18 & 3.88 \\
\hline 52 & & 8 & 0.74 & 0.14 & 4.04 & 0.58 & 4.77 & 0.71 & 14.10 & 3.31 & 18.88 & 3.3 & 37.77 & 5.92 & 56.65 & 8.54 \\
\hline 18 & 20 & 4 & 0.90 & 0.41 & 3.13 & 1.28 & 4.03 & 1.68 & 6.76 & 0.85 & 10.79 & 1.63 & 6.70 & 3.97 & 17.49 & 4.29 \\
\hline 32 & & 4 & 2.78 & 0.83 & 5.38 & 0.87 & 8.16 & 1.52 & $\mathbf{5 . 7 5}$ & 1.12 & 13.91 & 2.36 & 28.81 & 6.62 & 42.72 & 7.32 \\
\hline 52 & & 8 & 1.22 & 0.19 & 3.70 & 0.48 & 5.11 & 0.76 & 13.28 & 4.1 & 18.38 & 4.7 & 44.79 & 5.15 & 62.68 & 8.8 \\
\hline 18 & 24 & 4 & 1.77 & 0.65 & 5.08 & 1.44 & 6.85 & 2.06 & 20.33 & 5.27 & 27.18 & 5.78 & 3.14 & 1.58 & 30.32 & 6.42 \\
\hline 32 & & 4 & 6.56 & 2.2 & 7.50 & 2.9 & 14.05 & 5.08 & 9.78 & 1.15 & 23.83 & 6 & 13.22 & 4.86 & 37.05 & 10.4 \\
\hline 52 & & 8 & 4.99 & 1.12 & 6.76 & 1.55 & 11.76 & 2.57 & 7.77 & 2.13 & 19.53 & 3.61 & 37.83 & 2.7 & $\mathbf{5 7 . 3 6}$ & 4.92 \\
\hline 18 & 28 & 4 & 2.53 & 0.59 & 5.11 & 1.42 & 7.64 & 1.99 & 8.03 & 2.31 & 15.68 & 3.75 & 0.42 & 0.37 & 16.09 & 4.05 \\
\hline 32 & & 4 & 3.97 & 0.91 & 4.47 & 0.81 & 8.43 & 1.69 & 9.73 & 0.87 & 18.16 & 2.06 & 9.18 & 4.25 & 27.34 & 5.93 \\
\hline 52 & & 8 & 2.68 & 0.42 & 3.55 & 0.4 & 6.37 & 0.86 & 15.23 & 4.17 & 21.60 & 4.58 & 16.79 & 2.68 & 38.39 & 6.47 \\
\hline 18 & 32 & 4 & 1.87 & 0.42 & 3.46 & 0.45 & 5.33 & 0.87 & 8.85 & 2.84 & 14.18 & 3.56 & $\dagger$ & $\dagger$ & 14.18 & 3.56 \\
\hline 32 & & 4 & 5.92 & 1.87 & 4.10 & 0.55 & 10.02 & 2.13 & 12.47 & 1.5 & 22.48 & 3.36 & $\dagger$ & $\dagger$ & 22.48 & 3.36 \\
\hline 52 & & 8 & 5.06 & 0.98 & 4.91 & 0.84 & 9.97 & 1.55 & 15.66 & 2.4 & 25.63 & 2.94 & 1.99 & 0.83 & 27.62 & 3.46 \\
\hline
\end{tabular}

$\dagger$ No measurable tubers. 
for the harvest dates indicated that the temperature for maximum tuber weight decreased as time progressed. Based on the fitted coefficients, the calculated temperatures associated with maximum tuber weights were 22 , 20 , and $17^{\circ} \mathrm{C}$ for 18,32 , and $52 \mathrm{DAE}$, respectively. The relationship with temperature for total biomass was similar to the relationship for tuber weights where a quadratic relationship fit the data best. The linear coefficient for temperature varied with harvest date while the quadratic temperature coefficient was constant over harvest date. This suggests the temperature for maximum biomass did not change over time in contrast to the results for tuber weight. The linear effect of temperature did tend to decrease over time, however. This reflected the slowing of the growth of vegetative components and increase in growth of tubers.

The final tuber weights were highest for the $20^{\circ} \mathrm{C}$ temperatures with the 16 and $24^{\circ} \mathrm{C}$ temperatures (Table 2) having the next highest weights. The lowest tuber weights were in the 28 and $32^{\circ} \mathrm{C}$ temperature treatments. The tuber growth rate was very low in the $32^{\circ} \mathrm{C}$ treatment. Tubers of a large enough size to weigh were only found at the final harvest, 52 DAE. Mean total biomass was highest in the $20^{\circ} \mathrm{C}$ temperature $\left(62.68 \mathrm{~g}_{\text {plant }}{ }^{-1}\right)$. The plants in the three highest temperatures roughly doubled their biomass between 18 and 52 DAE. The plants in the three lowest temperatures tripled their biomass in the same period.

\section{Carbon Balance}

A C balance was calculated to relate cumulative $\mathrm{C}$ gain (Eq. [2]) to biomass. The relationship between cumulative $\mathrm{C}$ gain and measured dry matter per plant is given in Fig. 5. The relationship was linear and a common slope appeared adequate for all treatments. The plants in the two temperature treatments with the lowest $\mathrm{C}$ gain $\left(28\right.$ and $\left.32^{\circ} \mathrm{C}\right)$ had high respiration losses during days with low light levels (Fig. 3) and total daily $\mathrm{C}$ gain values less than zero (Fig. 4). The deviation from the regression line for the $24^{\circ} \mathrm{C}$ treatment can be partially

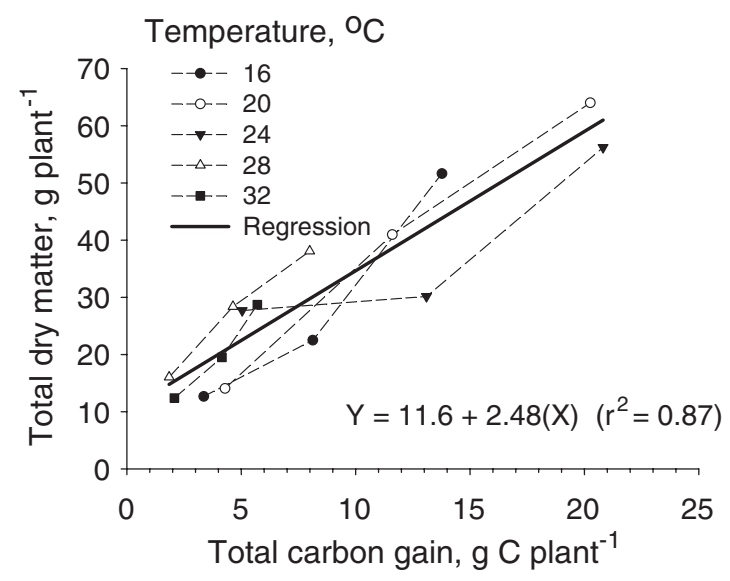

Fig. 5. Total dry matter per plant as a function of total $\mathrm{C}$ gain over the growing period. The dotted lines show the trends with time within a temperature. The dark, solid line shows the linear regression for biomass $=\mathbf{a}+\mathbf{b}$ (total $\mathbf{C}$ gain). attributed to the loss of leaves during senescence that we were not able to recover. The intercept for the line, $11.6 \mathrm{~g}$, is an estimate of seedling size after emergence and initial growth. The slope, $2.48 \mathrm{~g} \mathrm{D}_{\mathrm{M}} \mathrm{g} \mathrm{C}^{-1}$ is an estimate of the conversion efficiency of assimilated $\mathrm{C}$ to plant dry matter.

A similar balance for soybean using whole canopy $\mathrm{C}$ assimilation data gave an estimate of $1.5 \mathrm{~g} D_{\mathrm{M}} \mathrm{g} \mathrm{C}^{-1}$ (Jones et al., 1985) although roots were not measured. A slope of about 2.1 has been reported for pansy (Viola $\times$ wittrockiana Gams.) (van Iersel and Kang, 2002) for dry matter including roots but no seed. Dutton et al. (1988) reported a conversion factor of 2.51 and 2.82 for rose (Rosa spp.) and tomato (Lycopersicon esculentum Mill.), respectively. The conversion value for $\mathrm{C}$ to dry matter for potato is expected to be high relative to soybean due to the high carbohydrate content of the tuber. Furthermore, elevated $\mathrm{CO}_{2}$ decreases the $\mathrm{N}$ content of tubers (Donnelly et al., 2001) and thus increases the relative starch content. Seed material such as seeds from soybean plants that contain more fats and proteins than potato tubers have a higher stoichiometric conversion factor than nonseed materials (Amthor, 2000; Jones et al., 1985). Values of $1.314 \mathrm{~g} \mathrm{CH}_{2} \mathrm{O} \mathrm{g} \mathrm{g}^{-1}$ of seed and $1.102 \mathrm{~g} \mathrm{CH}_{2} \mathrm{O} \mathrm{g}^{-1}$ of nonseed plant material were used by Jones et al. (1985). Because of the lower stoichiometric conversion factor for tubers and nonseed materials, $1 \mathrm{~g}$ of $\mathrm{C}$ in a potato plant can produce more plant vegetative material or tuber than seed.

\section{DISCUSSION Photosynthesis}

Initial whole-canopy net photosynthetic rates (up to 12-14 DAE) were not differentiated by temperature. Because the plants were small, the differences may not have been detected. However, high temperatures have not been shown to reduce $P_{\mathrm{N}}$ on a leaf level for newly expanded leaves (Wolf et al., 1990; Thornton et al., 1996). On a whole plant level the adjustment of photosynthesis to temperature changes involves adjustment over a period of time. Canopy level photosynthesis was not changed with either 1-d temperature treatments (Baker et al., 1972) or within $10 \mathrm{~d}$ after imposition of a temperature change (Reddy et al., 1991) for cotton.

Differences in net canopy photosynthesis rates became evident starting at 12 to 14 DAE. Temperature accelerates growth and development. Plants grown under optimum conditions have larger canopies and intercept more light than plants grown under suboptimum conditions and hence will have higher gross canopy photosynthetic rates (Reddy et al., 1991). The number of leaves increased with temperature and plants grown at high temperatures had smaller but more numerous leaves (Table 2). The lack of linear or quadratic temperature effects on leaf weight suggests that differences in leaf size among the treatments were not a major factor in differences among the net canopy photosynthetic rates in this study. The $24^{\circ} \mathrm{C}$ treatment did have a larger leaf mass and area than the other treatments, however, especially at the second harvest date. The 
specific leaf area could also have been high for this treatment. Therefore, there was likely some effect of canopy size on $P_{\mathrm{N}}$ but it was difficult to detect statistical differences in leaf weight with the small number of samples and high variation. Differences in canopy architecture could also contribute to variation in canopy photosynthesis rates through the effect on light interception but we did not quantify these. We noticed that the leaves of the plants in the high temperature treatments were more erect than those in the lower temperature treatments.

The temperature dependence of $P_{\mathrm{N}}$ beginning at 12 to 14 DAE may also be partially related to tuber initiation. Because of potential damage to the root system, we did not measure tuber initiation times. However, in the field, tuber initiation has been reported to begin about 13 to $18 \mathrm{DAE}$ depending on temperature (Ingram and McCloud, 1984; Kooman et al., 1996b). The developing tubers, as a sink for photosynthesis would allow the plant to support higher rates of photosynthesis (Basu et al., 1999).

Temperature does reduce photosynthetic rates in mature leaves (Thornton et al., 1996). Increased stomatal resistance at high temperatures due to high vapor pressure deficits has not been shown to contribute to differences in photosynthesis at elevated temperatures. (Sarquis et al., 1996; Hammes and de Jager, 1990). It has been suggested that the effect of temperature on photosynthesis in potato is to disrupt the PS II cycle (Prange et al., 1990). Because disruption of PS II can also be a function of leaf aging (Murchie et al., 1999), it is possible that supra-optimal temperatures accelerate maturity leading to reductions in photosynthesis over time. New leaves are produced faster at high temperatures than at low, however (Table 1) so that canopy photosynthetic rates should not be affected so strongly by leaf aging while the plant is rapidly growing. Accelerated leaf aging probably increased in importance toward the end of the season. Leaf number reached close to its final number about 30 DAE for most of the treatments. The decrease in $P_{\mathrm{N}}$ after this time is likely due to aging of the canopy.

The optimum temperature for canopy $P_{\mathrm{N}}$ for most of the growing period was $24^{\circ} \mathrm{C}$, a value similar to the optimum reported for leaf level photosynthetic rates $(\mathrm{Ku}$ et al., 1977; Ghosh et al., 2000). The maximum rate of $P_{\mathrm{N}}$ in the $24^{\circ} \mathrm{C}$ chamber was about $24 \mu \mathrm{mol} \mathrm{m}{ }^{-2} \mathrm{~s}^{-1}$. Leach et al. (1982) using small field enclosures measured maximum daily values of canopy photosynthesis in potato of $0.6 \mathrm{~g} \mathrm{CO}_{2} \mathrm{~m}^{-2} \mathrm{~h}^{-1}$ (about $37 \mu \mathrm{mol} \mathrm{m} \mathrm{m}^{-1}$ ). The optimal temperature in our study was about $24^{\circ} \mathrm{C}$ at $18 \mathrm{DAE}$ but the differences among the three coolest temperatures $\left(16,20\right.$, and $\left.24^{\circ} \mathrm{C}\right)$ decreased as the growing season neared completion (Fig. 2). After $25 \mathrm{DAE}, P_{\mathrm{N}}$ for the $24^{\circ} \mathrm{C}$ treatment began to decline and the $P_{\mathrm{N}}$ rates for the 20 and $24^{\circ} \mathrm{C}$ treatments were not significantly different. This suggests a shift to a lower temperature as an optimum at longer growing times (Prange et al., 1990). This corresponds to a shift to lower temperatures in the optimum temperature for tuber growth as well.

The canopy net photosynthetic rates for the two coolest treatments $\left(16\right.$ and $\left.20^{\circ} \mathrm{C}\right)$ may have continued to rise had there not been a removal of plants from the chambers. The lack of a sharp decrease in canopy $P_{\mathrm{N}}$ in most of the treatments after the first destructive harvest may be due to two factors, (i) the plants were close to full light interception and the loss of four plants did not greatly reduce light interception or (ii) the upward trend in photosynthesis was cut off resulting in a leveling of the trend. Our plant density before the first harvest was about 16 plants per $\mathrm{m}^{-2}$. Compared to field levels of about four to five plants $\mathrm{m}^{-2}$, the plant density was high and the plants were probably intercepting much of the light.

The tubers in the 12 and $16^{\circ} \mathrm{C}$ treatments probably would have continued to grow for 7 or $14 \mathrm{~d}$ had we continued the experiment since the plants had not fully senesced at final harvest. The total calendar time required for the plants in these growth chambers to mature was less than calendar times in field studies in the northeastern USA. However the physiological time needed for the crop to mature for the four highest temperature treatments was likely hastened by the higher temperatures and maintenance of constant night time and day time temperatures. The short growing season of about $52 \mathrm{~d}$ and early senescence was also a function of the shortening daylength beginning in September. Short days accelerate tuber induction and maturity (Vos, 1999; Kooman et al., 1996b).

\section{Carbon Balance}

The maximum mean daily cumulative $\mathrm{C}$ gain calculated using Eq. [2] was about $0.9 \mathrm{~g} \mathrm{C} \mathrm{d}^{-1}$ plant $^{-1}$ during midseason in the $24^{\circ} \mathrm{C}$ treatment when the rates were at their highest. Using the conversion from $\mathrm{C}$ to dry matter from Fig. 5 this would be about $2.23 \mathrm{~g}$ dry matter $\mathrm{d}^{-1}$ plant $^{-1}$ or $2.62 \mathrm{~g} \mathrm{MJ}^{-1} \mathrm{~m}^{-2}$ PAR assuming 12 plants per $\mathrm{m}^{2}$ in the chamber and using the measured PAR of $10.2 \mathrm{MJ}$ for the day $\left(47 \mathrm{~mol} \mathrm{~m}^{-2} \mathrm{~d}^{-1}\right)$. This value of radiation use efficiency is comparable to the range of 1.95 to 3.6 measured by Kooman et al. (1996a) for a range of sites and planting dates in the Netherlands and Africa.

\section{Carbon Partitioning}

The $\mathrm{C}$ balance suggests that the effect of temperature on dry matter accumulation was largely through temperature's effect on cumulative $\mathrm{C}$ gain. The relationship between dry matter accumulation and $\mathrm{C}$ gain was constant over the different temperatures despite different amounts of $\mathrm{C}$ partitioning to the tubers among these three treatments. The cumulative $\mathrm{C}$ gain for the warmest temperature decreased over the latter part of the growing season due to high respiration rates. Since the dry matter increased, we should have measured a larger value of cumulative $\mathrm{C}$ gain after the first harvest. The gain in dry matter between the second and final harvest was small for the $32^{\circ} \mathrm{C}$ treatment, about $5 \mathrm{~g}$ and the standard error was about $3 \mathrm{~g}$. The daily $P_{\mathrm{N}}$ rates were also very small, especially toward the end of the season. As a result, they would have been more strongly affected by cumulative errors over the season, especially for respiration, than the data for the coolest treatments with higher $\mathrm{C}$ gain values. 
Overall, these data suggest that temperature affected partitioning and that the plants grown at high temperatures accumulated $\mathrm{C}$ but could not partition it to the tubers. Sarquis et al. (1996) attributed lower growth rates at high temperature to reduced net $\mathrm{C}$ assimilation rates resulting from higher respiration. This appears to have occurred on a canopy level in this study as well. The high respiration values in the two warmest treatments resulted in a negative $\mathrm{C}$ balance on some days, especially toward the end of the season as the proportion of young leaves decreased. This suggests the importance of respiration in the reduction of total $\mathrm{C}$ accumulation at low light levels, especially as the plant ages.

Temperature effects on partitioning are related to how sugars are translocated in potato. Heat-stressed leaves have less starch and more sucrose (Lafta and Lorenzen, 1995). Heat-tolerant varieties of potato tend to accumulate less starch and more sugars in the leaves than heatsensitive ones (Basu and Minhas, 1991). We did note significantly higher stem weights in the higher temperature treatments as was reported by Lafta and Lorenzen, (1995). It appears that at high temperatures, the shoot becomes an important sink for photosynthates (Basu and Minhas, 1991). When tubers were removed from potato plants, high levels of carbohydrates were shown to accumulate in leaves resulting in downregulation of photosynthesis (Basu et al., 1999). This suggests that heat stress has larger effects on translocation of sugars to tubers than on the production of sugars from photosynthesis. The inability to translocate carbohydrates and the resultant decrease in leaf photosynthesis (Basu and Minhas, 1991) appears to also affect canopy level photosynthesis as well.

The trend in respiration values followed the trend in $P_{\mathrm{N}}$, for example, increasing to a peak at midseason, and then decreasing (Fig. 3 and 4). Prange et al. (1990) also found a reduction in leaf level dark respiration over time. They hypothesized that high temperature could have reduced the availability of respiratory substrates due to reduction in the number of cells able to carry out respiration.

\section{Application to Simulation Models of Potato}

Because of the limited scope of this experiment (one variety, elevated $\mathrm{CO}_{2}$ ) the coeficients of the equations are not useful for parameterizing a simulation model. The data are useful, however to test the temperature response of a model. We used algorithms from SIMPOTATO (Hodges et al., 1992) to generate tuber yields under the same conditions used in this study using parameters for a Russet Burbank variety. The model simulates partitioning to tubers using a set of rules that are based on temperature, $\mathrm{C}$ assimilation (radiation use efficiency), and determinancy. Since this is a simulation model, temperature and $\mathrm{C}$ assimilation affect things like plant growth stage, leaf area index, and others that in turn affect partitioning and growth of tubers. Simulation output based on these rules gave responses of tuber growth to temperatures that were similar to the experimental results. The linear/quadratic response surface was similar, though the magnitudes of the tuber weights were different. These data and those from similar experiments provide a method to evaluate output from plant models to test and refine the rules that are encapsulated in the models.

\section{SUMMARY AND CONCLUSION}

Whole plant canopy level photosynthesis measurements were obtained for potato grown at five temperatures, $16,20,24,28$, and $32^{\circ} \mathrm{C}$ in sunlit growth chambers at elevated $\left(700 \mu \mathrm{mol} \mathrm{mol}{ }^{-1}\right) \mathrm{CO}_{2}$. Plant biomass for leaves, stems, roots, and tubers were measured by destructive harvest of four plants per sampling, three times during the $52 \mathrm{~d}$ growth period for the same temperatures and $12^{\circ} \mathrm{C}$. The optimum canopy net photosynthetic rates were measured at $24^{\circ} \mathrm{C}$ and the maximum biomass was measured in the $20^{\circ} \mathrm{C}$ treatment. Initial differences in canopy $P_{\mathrm{N}}$ up to 12 to $18 \mathrm{~d}$ after emergence were small. Leaf appearance rate was positively and linearly related with temperature.

The differences in net canopy photosynthesis among the temperature treatments increased over time and were related to differences in tuber growth and, at later stages, aging of the plant canopy. Overall, there did not appear to be strong temperature dependencies for the canopy scale photosynthetic process itself in the short term. The effects of accelerated aging on canopy photosynthesis were not apparent until later in the growth period where elevated temperatures hastened maturity of the leaves and reduced photosynthetic rates more rapidly over time as compared to lower temperatures. Partitioning of photosynthates to tubers also decreased as temperature increased having an optimum of $20^{\circ} \mathrm{C}$ in this study.

A C balance calculated from cumulative $\mathrm{C}$ gain and dry matter harvested was linear over all treatments having an intercept of $11.6 \mathrm{~g}$ and slope of $2.48 \mathrm{~g} \mathrm{dm} \mathrm{g}^{-1}$ $\mathrm{C}$ assimilated. Respiration was an important component of photosynthate loss as a function of temperature, especially as the plant canopy aged.

Understanding temperature response of potato crop development is important in building potato crop models. Measurement of whole plant photosynthesis rather than leaf level provides quantitative information on the integrated effect of temperature on whole-plant performance and photosynthesis that can be used to develop and evaluate crop models. The results of this study suggest that temperature effects on photosynthesis, respiration, and $\mathrm{C}$ partitioning are important processes and largely affect plant growth and development rates. The challenge for simulation modeling is to incorporate feedback mechanisms that account for sourcesink relationships as a function of temperature.

\section{ACKNOWLEDGMENTS}

We wish to acknowledge Mr. Jackson Fisher and Robert Jones for their technical assistance and Mr. Timothy Seitz with for help with data collection. We also wish to thank Dr. SooHyung Kim for helpful discussions, and Dr. Dinesh Uprety and Dr. Jonathan Ephrath for reviews of earlier drafts. 


\section{REFERENCES}

Amthor, J.S. 2000. The McCree-de Wit-Penning de Vries-Thornley Respiration Paradigms: 30 Years Later. Ann. Bot. (London) 86:1-20

Baker, D.N., J.D. Hesketh, and W.G. Duncan. 1972. Simulation of growth and yield in cotton: I. Gross photosynthesis, respiration, and growth. Crop Sci. 12:431-435.

Baker, J.T., L.H. Allen, Jr., K.J. Boote, and N.B. Pickering. 2000. Direct effects of atmospheric carbon dioxide concentration on whole canopy dark respiration in rice. Glob. Change Biol. 6:275-286.

Baker, J.T., S.-H. Kim, D.C. Gitz, D. Timlin, and V.R. Reddy. 2004. A method for estimating carbon dioxide leakage rates in controlledenvironment chambers using nitrous oxide. Environ. Exp. Bot. 51 103-110.

Basu, P.S., and J.S. Minhas. 1991. Heat tolerance and assimilate transport in different potato genotypes. J. Exp. Bot. 42:861-866.

Basu, P.S., A. Sharma, I.D. Garg, and N.P. Sukumaran. 1999. Tuber sink modifies photosynthetic response in potato under water stress. Environ. Exp. Bot. 42:25-39.

Ben Khedher, M., and E.E. Ewing. 1985. Growth analysis of eleven potato cultivars grown in the greenhouse under long photoperiods with and without heat stress. Am. Potato J. 62:537-554.

Donnelly, A., T. Lawson, J. Craigon, C.R. Black, J.J. Colls, and G. Landon. 2001. Effects of elevated $\mathrm{CO}_{2}$ and $\mathrm{O}_{3}$ on tuber quality in potato (Solanum tuberosum L.). Agric. Ecosyst. Environ. 87:273-285.

Driver, C.M., and J.G. Hawkes. 1943. Photoperiodism in potato. Technical Communication, 10. Imperial Bureau of Plant Breeding and Genetics, Cambridge, UK

Dutton, R.G., J. Jiao, M.J. Tsujita, and B. Grodsinski. 1988. Whole plant $\mathrm{CO}_{2}$ exchange measurements for nondestructive estimation of growth. Plant Physiol. 86:355-358.

Ewing, E.E., and P.C. Struik. 1992. Tuber formation in potato: Induction, initiation, and growth. Hortic. Rev. (Am. Soc. Hortic. Sci.) 14:89-198.

Ghosh, S.C., K. Asanuma, A. Kusutani, and M. Toyota. 2000. Leaf gas exchange properties of potato under different temperature and soil moisture at different growth stages. Environ. Control Biol. 229-239.

Gough, C.M., J.R. Seiler, and C.A. Maier. 2004. Short-term effects of fertilization on loblolly pine (Pinus taeda L.) physiology. Plant Cell Environ. 27:876-886.

Hammes, P.S., and J.A. de Jager. 1990. Net photosynthetic rate of potato at high temperatures. Potato Res. 33:515-520.

Hodges, T., S.L. Johnson, and B.S. Johnson. 1992. SIMPOTATO: A highly modular program structure for an IBSNAT style crop simulation. Agron. J. 84:911-915.

Hui, D., Y. Luo, W. Cheng, J.S. Coleman, D.W. Johnson, and D.A. Sims. 2001. $\left[\mathrm{CO}_{2}\right]$ Canopy radiation- and water-use efficiencies as affected by elevated. Glob. Change Biol. 7:75-91.

Ingram, K.T., and D.E. McCloud. 1984. Simulation of potato crop growth and development. Crop Sci. 24:21-27.

Jones, P., J.W. Jones, and L.H. Allen, Jr. 1985. Seasonal carbon and water balance of soybeans grown under stress treatment in sunlit chambers. Trans. ASAE 28:2021-2028.

Kooman, P.L., A.J. Haverkort, P.L. Kooman, M. Fahem, and P. Tegera. 1996a. Effects of climate on different potato Genotypes: I. Radiation interception, total and tuber dry matter production. Eur. J. Agron. 5:193-205.

Kooman, P.L., A.J. Haverkort, P.L. Kooman, M. Fahem, and P. Tegera. 1996b. Effects of climate on different potato Genotypes: II. Dry matter allocation and duration of the growth cycle. Eur. J. Agron. 5:207-217.

Ku, S.B., G.E. Edwards, and C.B. Tanner. 1977. Effects of light, carbon dioxide, and temperature on photosynthesis, oxygen inhibition of photosynthesis, and transpiration in Solanum tuberosum. Plant Physiol. 59:868-872.

Kyei-Boahen, S., T. Astatkie, R. Lada, R. Gordon, and C. Caldwell. 2003. Gas exchange of carrot leaves in response to elevated $\mathrm{CO}_{2}$ concentration. Photosynthetica 41:597-603.

Lafta, A.M., and J.H. Lorenzen. 1995. Effect of high temperature on plant growth and carbohydrate metabolism in potato. Plant Physiol. 109:637-643.

Law, R.D., and S.J. Crafts-Brandner. 1999. Inhibition and acclimation of photosynthesis to heat stress is closely correlated with activation of Ribulose-1,5-Bisphosphate Carboxylase/Oxygenase. Plant Physiol. 120:173-182.
Leach, J.E., K.J. Parkinson, and T. Woodhead. 1982. Photosynthesis, respiration and evaporation of field-grown potato crop. Ann. Appl. Biol. 101:377-390.

Levy, D. 1986. Genotypic variation in the response of potatoes (Solanum tuberosum L.) to high ambient temperatures and water deficit. Field Crops Res. 15:85-96.

Littell, R.C., G.A. Milliken, W.W. Stroup, and R.D. Wolfinger. 1996 SAS system for mixed models. SAS Inst., Cary, NC.

Manrique, L.A., and D.P. Bartholomew. 1991. Growth and yield performance of potato grown at three elevations in Hawaii: II Dry matter production and efficiency of partitioning. Crop Sci. 31:367-379.

Marinus, J., and K.B.A. Bodlaender. 1975. Response of some potato varieties to temperature. Potato Res. 18:189-204.

Menzel, C.M. 1985. Tuberization in potato at high temperatures: Interaction between temperature and irradiance. Ann. Bot. (London) 55:35-39.

Murchie, E.H., Y. Chen, S. Hubbart, S. Peng, and P. Horton. 1999. Interactions between senescence and leaf orientation determine in situ patterns of photosynthesis and photoinhibition in field-grown rice. Plant Physiol. 119:553-564

Oparka, K.J., and H.V. Davies. 1985. Translocation of assimilates within and between potato stems. Ann. Bot. (London) 56:45-54.

Pickering, N.B., L.H. Allen, Jr., S.L. Albrecht, P. Jones, J.W. Jones, and J.T. Baker. 1994. Environmental plant chambers: Control and measurement using CR-10 data loggers. p. 29-35. In D.G. Watson et al. (ed.) Computers in Agriculture. Proc. of the 5th Int. Conf. Orlando, FL. 5-9 February. Am. Soc. of Agric. Eng., St. Joseph, MI

Prange, R.K., K.B. McRae, D.J. Midmore, and R. Deng. 1990. Reduction in potato growth at high temperature: Role of photosynthesis and dark respiration. Am. Potato J. 67:357-369.

Reddy, K.R., J.T. Baker, V.R. Reddy, J. McKinion, L. Tarpley, and J.J. Read. 2001. Soil-Plant-Atmosphere-Research (SPAR) facility: A tool for plant research and modeling. Biotronics 30:27-50.

Reddy, V.R., B. Acock, and M.C. Acock. 1989. Seasonal carbon and nitrogen accumulation in relation to net carbon dioxide exchange in a carbon dioxide enriched soybean canopy. Agron. J. 81:78-83.

Reddy, V.R., D.N. Baker, and H.F. Hodges. 1991. The effects of temperature on cotton canopy growth, photosynthesis, and respiration. Agron. J. 83:699-704.

Sands, P.J., C. Hacket, and H.A. Nix. 1979. A model for the development and bulking of potatoes (Solanum tuberosum L.): I. Derivation from well-managed field crops. Field Crops Res. 2:309-331.

Sarquis, J.I., H. Gonzalez, and I. Bernal-Lugo. 1996. Response of two potato clone (S. tuberosum L.) to contrasting temperature regimes in the field. Am. Potato J. 73:285-300.

SAS Institute. 1999. SAS/STAT user's guide. Version 8. SAS Inst., Cary, NC.

Thimijan, R.W., and R.D. Heins. 1983. A review of conversion constants and procedures for photometric, radiometric, and quantum light units of measure. HortScience 18:818-822.

Thornton, M.K., N.J. Malik, and R.B. Dwelle. 1996. Relationship between leaf gas exchange characteristics and productivity of potato clones grown at different temperatures. Am. Potato J. 73:63-77.

van Iersel, M.W., and J.G. Kang. 2002. Nutrient solution concentration affects whole-plant $\mathrm{CO}_{2}$ exchange and growth of sub-irrigated pansy. J. Am. Soc. Hortic. Sci. 127:423-429.

Vos, J. 1999. Split nitrogen application in potato: Effects on accumulation of nitrogen and dry matter in the crop and on the soil nitrogen budget. J. Agric. Sci. 133:263-274.

Williams, M.M., II, and R.A. Boydston. 2002. Effect of shoot removal during tuberization on volunteer potato (solanum tuberosum) tuber production. Weed Technol. 16:617-619.

Wolf, S., A.A. Olesinski, J. Rudich, and A. Marani. 1990. Effect of high temperature on photosynthesis in potatoes. Ann. Bot. (London) 65:179-185.

Wolf, J., and M. van Oijen. 2003. Model simulation of effects of changes in climate and atmospheric $\mathrm{CO}_{2}$ and $\mathrm{O}_{3}$ on tuber yield potential of potato (cv. Bintje) in the European Union. Agric. Ecosyst. Environ. 94:141-157.

Yamaguchi, M., H. Timm, and A.R. Spurr. 1964. Effects of soil temperature on growth and nutrition of potato plants, and tuberization, composition and periderm structure of tubers. Proc. Am. Soc. Hortic. Sci. 84:412-423. 